\title{
Importance of Professional Competency of Extension Personnel
}

\author{
Manoher Saryam ${ }^{1 *}$ and Pooja Jena ${ }^{2}$ \\ ${ }^{1}$ Department of Extension Education, Institute of Agricultural Sciences, \\ BHU, Varanasi (U.P.), India \\ ${ }^{2}$ Department of Extension Education, College of Agriculture, Rewa (M.P), India \\ *Corresponding author
}

\section{A B S T R A C T}

\begin{tabular}{|l|}
\hline Ke y w o r d s \\
Professional \\
Competency, \\
Extension, \\
Learning, Education \\
\hline Article Info \\
\hline $\begin{array}{l}\text { Accepted: } \\
\text { 12 September } 2019 \\
\text { Available Online: } \\
\text { 10 October } 2019\end{array}$ \\
\hline
\end{tabular}

\section{Introduction}

The concept of competence is probably as old as humankind. Homo sapiens have always been desiring to master skills and to find ways to solve practical, professional and scientific challenges. Certain individuals always received the prerogative to perform certain
Professional and practice-based learning is a procedure which shows itself in a wide range of structures. It varies by close to home attributes of the students, levels of their callings, fields of training, deliberateness of their learning, and formalization of the learning exercises. Ideas of skill have entered this assorted practice from numerous points of view. The inquiry is whether originations of expert ability have helped the act of expert and practice-based learning. In this section it is contended this is without a doubt the case. Albeit different endeavors to actualize capability based proficient learning projects were vigorously scrutinized, later improvements in fitness hypothesis and research gave new bits of knowledge which underscored the integrative significance of ability inside expert practice. It helped in mapping proficient fields from a domain specific just as a nonexclusive conduct point of view. This part goes into the underlying foundations of the skill development, and assesses the commitments of these to the field of expert and practice-based learning. This is additionally outlined with instances of various callings in which ability models have been and still are a viable way to delineate for expert practice and to direct the assessment and advancement of expert and practice based learning programs. What worked and did not work is then clarified by recognizing three methodologies of conceptualizing skill which have been utilized in various settings, and which have wide ramifications for expert and practice-based learning. The section closes with the case that present fitness originations help mapping, centering and surveying proficient and practice-based learning. 
The drive of individuals to learn to perform in certain fields of activities, however, never changed, and is to a large extent based on eagerness to master certain skills, become independent and get recognition. This is very well visible in babies and toddlers when they want to turn in their cradle, crawl on the floor and walk in the room, stimulated by their parents who are cheering when the first steps are taken. Young children constantly move around until they are able to do what they desperately want at the end of the day: to gain independence; or: to become competent. For gaining an independent position in society nowadays, individuals need to pass through formal education trajectories and complete examinations. The higher the education levels students achieve, the higher their chances of getting a good position at the labour market and an appointment in a better-paid and stable job. Independence, however, is a relative notion. In society, people are interdependent by definition, but individual ego development is necessary for getting a personal identity in the first place and a professional identity later in life, for which recognition is needed, by getting an appropriate education qualification, and subsequently by being appointed in a job, being promoted, rewarded, and having a career perspective. Development opportunities are the top priority of graduates from higher education and considered to be a major labour condition. Because of the massification of education, it became an industry. And because of its limited innovation capacity, it somehow alienated from society. Getting a diploma became a goal in itself, many educational institutions were not well-aligned to societal demands anymore, and became pedagogical islands. Sometimes this process is called the 'diploma disease', but it can also be named the 'competence crisis', as the big issue was whether graduates who were qualified really were able to perform according to standards in the profession and expectations in the working situation. Having a college degree was no guarantee for being able to perform well on the job or in society in general.

The increasing changes in and demand for high quality and quantity of farm produce made on agricultural based institutions and farmers in the 21st century have had a considerable impact on roles and job performance of extension workers. As a result, the traditional subsistence agriculture is gradually been replaced by market-oriented or commercial agriculture. This is probably due to factors including rapid economic growth in both developing and developed countries, introduction of new technologies, market expansion, market liberalization, increased demand for food, decreasing farming population as result of urbanization, liberalized and open economic policies, bilateral and multilateral economic agreements, developed infrastructure facilities in farming areas and government agricultural policies (Mahaliyanaarachchi and Bandara, 2006). Improvement in general agricultural production, productivity and sustainability will depend on farmers' willingness and access to new technology.

Agricultural extension and advisory services play an important role in addressing this challenge. Agricultural extension services play a pivotal role in ensuring that the farmers have access to improved and proven technologies and that their concerns and needs are properly addressed by relevant service providers. Agricultural extension contributes to improving the welfare of farmers and other people living in rural areas as extension advisory services and programmes forges to strengthen the farmer's capacity to innovate by providing access to knowledge and information. However, the role of extension today goes beyond technology transfer to facilitation; beyond training to learning, and includes assisting farmer to form groups, dealing with marketing issues, addressing 
public interest issues in rural areas such as resource conservation, health, monitoring of food security and agricultural production, food safety, nutrition, family education, and youth development and partnering with a broad range of service providers and other agencies (USAID, 2002). This has led to increasing emphasis on the development of core competencies necessary for the extension workers to perform at maximum. Competent extension professionals are the assets of agricultural extension services. Diverse and dynamic agricultural systems, advancing science and technologies, changing sociodemographics, increasing globalization and growing competition for resources demand agricultural extension professionals to be proficient in the technical aspects of their areas of expertise, as well as in the processes and delivery of the services (Cochran, Ferrari, and Chen, 2012; Gibson and Brown, 2003; Maguire, 2012; Melak and Negatu, 2012; Rivera et al., 2009; Swanson and Rajalahti, 2010). In other words, the need and demand for extension professionals to demonstrate a higher level of professionalism in their services are growing.

The scope of agricultural extension services (AES) has been widening, and the need to adapt to changing contexts is also growing. AES should work in sustainable agricultural development and play coordinating and leadership roles among agricultural stakeholders (Rajalahti, 2012; Swanson, 2008). The challenges include offering new services, ensuring the quality of services, and strengthening collaboration and synergy among extension service providers (Sulaiman and Davis, 2012). Furthermore, AES should become more participatory, demand-driven and pluralistic (Rivera et al., 2009). This means that, in order to thrive, extension must understand and adjust to rapid changes and emerging challenges (ECOP, 2002). These calls for organizational changes and new tasks indicate the need for multi-skilled human resources in extension services (Cochran, 2009).

Therefore, the effectiveness of an Extension organization is determined by the ability of extension agents to design, deliver, and evaluate effective educational programs, because they are directly serving the needs of the people. Their ability to perform extension tasks is a function of their job competencies. To (Severs et al., 2007), future extension professionals need to be more skillful and futuristic to serve the needs of diverse audience. Extension staff must learn new knowledge and skills, since it is only knowledgeable and skillful individual who can play a vital role in the success of an organisation in today's technological environment. According to Swanson (1996), high value should be placed on core competencies in business and industry, primarily referring to their knowledge and expertise in these fields. To be a successful extension staff today, one must be competent not only in technical matters, but also in areas such as management, programming communication, human relations, and. As a result, it is necessary to investigate competencies of extension staff and how that leads to better delivery of extension services for a sustainable rural development.

\section{What is professional competence?}

Professional is competent when he/she acts responsibly and effectively according to given standards of performance. One can also say that this professional possesses sufficient competence.

Professional competence is seen as the generic, integrated and internalized capability to deliver sustainable effective (worthy) performance (including problem solving, realizing innovation, and creating 
transformation) in a certain professional domain, job, role, organisational context, and task situation.

Competence consists of various competencies. A competency is a part of generic competence; it is a coherent cluster of knowledge, skills and attitudes which can be utilized in real performance contexts. For instance, in a crime scene investigation a forensic expert needs to produce a DNA profile of a piece of evidence. This requires knowledge (disciplinary knowledge), skills (working with artefacts) and attitudes (accuracy, coping with pressure, integrity). Together these constitute professional competence. Or traders at a flower auction: they require knowledge (about the products, quality indicators, market developments, prices), skills (multi-tasking, processing information, instant decision making), and attitudes (stress-tolerance, feeling for sales). These are elements of professional competence as well.

What has not yet been discussed often it the twofold meaning of competence in terms of capabilities and rights. These two are different, yet go together. Competence as capabilities is the field professionals feel comfortable with. Because of their education and experience in practice they have gained a certain level of competence, which goes together with a feeling of confidence, selfefficacy and professional identity. But educational institutions have declared graduates to be competent by approving their completions. The diploma is the formal piece of evidence of the competence level of the graduate, which is nowadays more transparent because of the education levels specified in the European Qualification Framework and printed on diplomas or in diploma supplements. Professional associations also declare individuals as competent when they comply with certain standards. Educational institutes and professional associations have the right to do so if they are acknowledged by the relevant institutions. We can also say that educational institutions have the competence to take decisions regarding the licensure of candidates who complete educational programs. Other institutions may have other rights, such as law courts and European institutions. Examples of institutional competencies of law courts were already described in the dissertations of Viruly (1890) and Roes (1885) at the University of Leiden in the Netherlands. (Both dissertations counted 31 and 41 pages respectively). Individuals who have received a professional licence of an educational institute or a professional association, or the state, also have certain rights to act (e.g. as teacher), perform interventions (e.g. as medical expert), and take decisions (as lawyer). Citizens also have their rights (to vote, to raise children, to move in freedom), but if there are grounded reasons to do so, the legal system can also deny these rights by declaring people incompetent. The meaning of competence discussed above is mainly related to professional competence, as used in key competencies, competence domains, competence clusters, enabling competencies, and competency dimensions or competency components. However, there is also a branch of literature in which organizational competence is being discussed. The most prominent source of this is probably the work of Prahalad and Hamel (1990) on the core competence of organisations. Core competencies are capabilities of organisations in which they excel, with which they earn most of their profits, and which cannot easily be copied by competitors. This is an interesting line of research, and at organisational level core competencies should be included in the corporate strategy, which should be aligned with corporate human resources management strategy, which in turn should be related to the corporate competence development strategy. 
The relationship between competence and professional performance is complicated. There are multiple connections between the two at various levels of aggregation and relationships between detailed competencies en specific performance results are not exclusive. Utilizing criterion differentiation and canonical correlation in the search for common dimension of competence and performance as suggested by Bartram (op cit) is nevertheless useful.

\section{Emerging Roles of Agricultural Extension Services}

Scholars have highlighted the need for active participation of farmers in extension processes, including decision making, so that farmers can voice their needs and can demand and get programs that they deem appropriate (Rivera et al., 2009). Others have emphasized participation, collaboration and cooperation among extension service providers in various aspects of extension services, such as in knowledge, information and resource sharing (Swanson \&Samy, 2002; ECOP, 2002).

"Extension" means to extend education or to educate people with the aim of bringing positive behavioral changes and improving the quality of life among those targeted (Qamar, 2005). Dwarakinath (2006) said that communication and adult education are two facets of extension education. Extension professionals need to have knowledge of andragogy - how adults learn. Suvedi and McNamara (2012) underscored that communication and coordination between extension and research are crucial in agricultural services. Extension professionals should know about ongoing research and research findings, and researchers must know what field-researchable problems are. Moreover, demand for information and communication technologies (ICTs) in agricultural extension services is ever growing
(Aker, 2011). The use of ICTs makes information dissemination quicker, easier and cheaper. Extension professionals should be cognizant of the new ICTs and use them in their work. Facilitating farmers in marketing their products and educating community members to mitigate the risks of climate changes are other tasks that extension agents are now asked to do. It is difficult for extension professionals to accomplish these tasks on their own. Extension services will be sustainable if they follow a farmer-centered (demand-driven) approach, encourage participation of farmers and other stakeholders in extension processes (participatory), and involve NGOs and farmer cooperatives as extension service providers (pluralistic).

\section{Core Competencies for Extension Professionals}

Adapted from Liles and Mustian (2004), Maddy et al., (2002), Ohio State University (2015), Suvedi (n. d.), Vandenberg and Foerster (2008), and the studies from developing countries in Asia and Africa, core competencies and associated competencies are listed below that Nepal may consider adapting for its extension professionals. However, the need for competencies is context-specific (Mulder, 2014) and culture-specific, and extension education is a lifelong learning process (ECOP, 2002) whose core competencies are subject to change as new situations unfold.

Program planning and implementation are important skills that extension professionals need.

In a study done among extension agents, Gibson and Hillison (1994) found program planning rated as the most important competency need. Extension professionals not only have to understand planning and do planning within their organizations, they also 
have to facilitate their clients in doing the same. It is thus important that extension professionals should be able to:

Understand policies, programs and strategies of agricultural development

Comprehend demographics, economic and human activity systems of the communities they serve.

Assess the needs of farmers and other stakeholders.

Identify, acquire and allocate resources to programs according to their priority.

Establish working relationships with partners.

Design and implement programs with stakeholders' participation.

Use appropriate educational design to respond to local learning needs.

Apply adult learning principles to extension education and training.

Provide input to and seek feedback from participants/learners/clients.

\section{Communication skills}

Communication is one of the pillars of extension because extension professionals have to communicate effectively with their clients and stakeholders. Extension professionals should:

Know various types and styles of communication and be able to use them.

Engage in adaptation of new technologies.

Demonstrate good speaking skills. Demonstrate effective listening skills.
Be able to create concise reports and proposals of their extension programs.

Select and practice communication tools and methods that suit recipients and their needs.

Be aware of local dialects and cultures while communicating with clients.

\section{Education and informational technology}

The use of appropriate methods, messages and tools of education and information is of paramount importance in extension.

Competency of extension professionals will be evaluated on the basis of how familiar they are with various and emerging ICTs and other communication tools and methods and how effectively they use these tools and methods in their routine work. Extension professionals should be able to:

Use computers for word processing, information access, data storage and analysis.

Provide information via local radio stations, the Internet and mobile phones.

Effectively use audiovisual materials for teaching adults.

Use television and radio to communicate information to clients.

Design and use educational materials on the basis of clients' needs and contexts.

\section{Leadership}

A large number of stakeholders are involved in and/or associated with agricultural services. Extension professionals have the challenge to lead, coordinate and facilitate these diverse stakeholders. Extension professionals should uphold stakeholders' participation and 
ownership in the programs. Moreover, they should:

Understand group dynamics, work in a team and encourage teamwork in their organizations.

Understand basic approaches to conflict resolution.

Understand facilitation and the role of facilitators.

Identify major political forces that operate in the communities.

Use a variety of leadership approaches depending on their work contexts.

Practice consensus decision making among clients and stakeholders.

Understand barriers to participation and/or learning.

Be able to interact successfully with diverse individuals and groups to create partnerships and networks.

Delegate tasks to staff members.

\section{Diversity, pluralism and multiculturalism}

Most developing countries, are home to many races, cultures, religions and ethnicities. Gender-related issues, such as gender disparities in services, are frequently raised in these countries. If extension professionals need to be familiar with the diversities of the communities they serve. Specifically, they should be able to:

Demonstrate sensitivity to the diverse needs of various cultural groups in the community. Engage and enhance the participation of various ethnic and sociocultural groups in extension programs.

Ensure that women and farmers from rural areas and marginalized groups participate in the extension programs.

Identify, understand and appreciate the needs of diverse staff members and clients.

Understand and update diversity and multiculturalism issues.

Ensure that other service providers (e.g., private sector agencies, NGOs, farmer cooperatives, etc.) collaborate in AES and/or provide extension services to the clients.

\section{Program evaluation and research}

Monitoring and evaluation of programs are as important as program planning. Funders and stakeholders are eager to know whether the extension programs yield expected outcomes.

Program evaluation is the most studied among the core competencies for extension professionals (Rodgers et al., 2012). Scholars have found program evaluation to be one of the important competencies required for extension professionals (Khalil et al., 2009; Namdar et al., 2010).

Extension professionals should have information about what, where, how and when extension programs are delivered and how successful these programs have been. In light of these demands, extension professionals should also:

Understand theories of monitoring and evaluation.

Understand and adopt formative and summative evaluations. 
Do regular monitoring of extension programs and services.

Apply quantitative and qualitative data analysis tools, techniques to analyze and interpret monitoring, and evaluation data.

Communicate monitoring and evaluation findings to clients-farmers, researchers, educators, line agencies and departments.

Improve and/or redesign programs on the basis of evaluation results.

Remain current with extension-related research findings and research approaches.

\section{Extension and organizational management}

To deliver extension programs effectively, extension organizations need to function well.

Extension professionals should therefore establish structure, organize processes, develop and monitor resources, and lead change to obtain extension outcomes effectively and efficiently (Maddy et al., 2002). They should also:

Understand and be able to convey information about the vision, mission and goals of the extension services.

Communicate effectively with staff members and clients.

Conduct staff appraisal and keep staff members informed of their performance.

Effectively implement reward and punishment systems in their respective offices.

Find out staff needs - human resource development and others - and address them.
Organize staff meetings in a timely manner and seek staff input.

\section{Professionalism}

Extension professionals should:

Have a strong work ethic.

Be committed to continuous learning and career advancement.

Have a positive attitude about extension work.

Be accountable to their clients.

Adhere to their professional norms.

Maintain transparency.

Demonstrate critical thinking and problemsolving skills.

Be able to work independently.

\section{Technical subject matter expertise}

Together with the process skills, extension professionals should be proficient in their subject matter. They should:

Demonstrate that they have basic knowledge in their discipline.

Understand the new technology being promoted -- what it is, and why and how it works.

Be able to educate community members about risks and uncertainties due to climate change, market fluctuations, disasters, etc.

Refer to and make use of publications, research reports, etc. 
Demonstrate basic knowledge of agribusinesses and help entrepreneurship development among extension clients.

The development of a unified approach to the determination of the essence and structure of global competence and its place in extension professional competence will help to organize national (regional) strategies of development of policies and Programme with a focus on the challenges and prospects of the age of globalization.

\section{References}

Aker, J. C. (2011). Dial "A" for agriculture: Using information and communication technologies for agricultural extension in developing countries. Agricultural Economics, 42(6), 631-647.

Cochran, G. (2009). Ohio State University extension competency study: Developing a competency model for a 21 st century extension organization. Doctoral dissertation. Retrieved from https://etd.ohiolink.edu/.

Cochran, G. R., Ferrari, T. M., and Chen, C. Y. T. (2012). Trends affecting Ohio State University extension in the 21st century and the implications for human capital. Journal of Agricultural Education, 53(2), 43-57.

Dwarakinath, R. (2006). Changing tasks of extension education in Indian agriculture. Pages 56-80 in A. Van den Ban, and R. Samanta (Eds.), Changing roles of agricultural extension in Asian nations. Delhi, India: B.R. Publishing Corporation.

Extension Committee on Organization and Policy (ECOP). (2002). The extension system: A vision for the 21st century. Retrieved from http://dasnr2.dasnr. okstate.edu/documents/committee_rep ort.pdf.
Gibson, J. D., and Brown, A. S. (2003). Use of managerial proficiencies in agricultural and extension education: An assessment of Virginia Cooperative Extension. Journal of International Agricultural and Extension Education, 10(3), 19-24.

Gibson, J. D., and Hillison, J. (1994). Training needs of area specialized extension agents. Journal of Extension, 32(3). Retrieved January 16, 2015, from http://www.joe.org/joe/1994october/a3 .php.

Khalil, A. H. O., Ismail, M., Suandi, T., and Silong, A. D. (2009). Human resource development competencies as predictors of agricultural extension agents' performance in Yemen. Human Resource Development International, 12(4), 429-447.

Liles, R. T., \&Mustian, R. D. (2004). Core competencies: A systems approach for training and organizational development in extension. The Journal of Agricultural Education and Extension, 10(2), 77-82.

Maddy, D. J., Niemann, K., Lindquist, J., and Bateman, K. (2002). Core competencies for the cooperative extension system. Oregon State University Extension Service. Retrieved November 22, 2014, from https://www.msuextension.org/jobs/for ms/Core_Competencies.pdf.

Maddy, D. J., Niemann, K., Lindquist, J., and Bateman, K. (2002). Core competencies for the cooperative extension system. Oregon State University Extension Service. Retrieved November 22, 2014, from https://www.msuextension.org/jobs/for ms/Core_Competencies.pdf.

Maguire, C. J. (2012). Agricultural education and training to support agricultural innovation systems. In Agricultural innovation systems: An investment 
sourcebook. Washington, DC: World Bank

Melak, D., and Negatu, W. (2012). Agricultural education and technical competency of development agents in Ethiopia. Journal of Agricultural Extension and Rural Development, 4(11), 347-351. doi: 0.5897/JAERD11. 114

Mulder, M. (2014). Conceptions of Professional Competence. In: S. Billett, C. Harteis, H. Gruber (Eds). International Handbook of Research in Professional and Practice-based Learning. Dordrecht: Springer. pp. 107-137.

Mulder, M. (2014). Conceptions of professional competence. Pages 107137 in S. Billett, C. Harteis, and H. Gruber (Eds.), International handbook of research in professional and practice-based learning. Netherlands: Springer.

Namdar, R., Rad, G. P., and Karamidehkordi, E. (2010). Professional competencies needed by agricultural and extension program evaluation staff and managers of Iranian Ministry of Agriculture. Journal of International Extension and Education, 17(2), 17-31. doi:10.5191/jiaee.2010.17202.

Ohio State University. (2015). Core competencies. Retrieved January 10, 2015, from http://extensionhr.osu.edu/ compmodel/corecomp.htm.

Prahalad, C.K. and G. Hamel (1990). The Core Competence of the Corporation, Harvard Business Review, May-June, pp. 79-91.

Qamar, M. K. (2005). Modernizing national agricultural extension systems: A practical guide for policy-makers of developing countries. Food and Agricultural Organizations (FAO). Available at http://www.fao.org/docrep/
008/a0219e/a0219e00.htm\#Contents.

Rajalahti, R. (2012). Sourcebook overview and user guide. In Agricultural innovation systems: An investment handbook. Washigton, D.C.: World Bank.

Rivera, W., Blum, M., and Sulaiman, R. (2009). Extension: Object of reform, engine for innovation. Outlook on Agriculture, 38(3), 267-273.

Rivera, W., Blum, M., and Sulaiman, R. (2009). Extension: Object of reform, engine for innovation. Outlook on Agriculture, 38(3), 267-273.

Rodgers, M. S., Hillaker, B. D., Haas, B. E., and Peters, C. (2012). Taxonomy for assessing evaluation competencies in extension. Journal of Extension, 50(4), 4FEA2.

Roes, G.B. (1885). Twee vragenbetreffende de absolute competentie van den kantonrechter. Leiden: Somerwil. (academischproefschrift).

Seevers, B., D. Graham, J. Gamon, and N. Conklin, 2007. Education through Cooperative Extension. New York: Delmar Publishers

Sulaiman, R. V., and Davis, K. (2012). The 'new extensionist': Roles, strategies, and capacities to strengthen agricultural and advisory services. Lindau, Switzerland: Global Forum for Rural Advisory Services (GFRAS)

Suvedi, M. (n.d.). Capacity building for agricultural knowledge management: Challenges facing the agricultural extension profession. Unpublished manuscript. East Lansing, MI: Department of Community Sustainability, Michigan State University.

Suvedi, M., and McNamara, P. (2012). Strengthening the pluralistic agricultural extension system in Nepal. Lansing: MSU/MEAS/USAID. Retrieved October 15, 2014, from 
https://docs.google.com/viewer?a=v\&p $\mathrm{id}=$ sites\&srcid=bWVhcy1leHRlbnNpb 24ub3JnfHB1YmxpY3xneDo3ZmQ3 Mjc3ZmM4OTNjOTc5.

Swanson, B. E. (2008). Global review of good agricultural extension and advisory service practices. Rome, Italy: Food and Agricultural Organizations (FAO).

Swanson, B. E., and Rajalahti, R. (2010). Strengthening agricultural extension and advisory systems: Procedures for assessing, transforming, and evaluating extension Systems. Washington, D.C.: The World Bank.

Swanson, B. E., and Samy, M. M. (2002). Developing an extension partnership among public, private, and non- governmental organizations. Journal of International Agricultural and Extension Education, 9(1), 5-10.

Swanson, R. A. (1996). Analysis for improving performance: Tools for diagnosing organizations and documenting workplace expertise. San Francisco, CA: Berret- Kpehler.

Vandenberg, L., and Foerster, K. (2008). Core competencies in MSU extension. East Lansing, MI: Michigan State University Extension.

Viruly, M.A.M. (1890). De relatieve competentie van den kantonrechtervolgens art. 97 en 98 B.R.V. Leiden: Somerwil.

\section{How to cite this article:}

Manoher Saryam and Pooja Jena. 2019. Importance of Professional Competency of Extension Personnel. Int.J.Curr.Microbiol.App.Sci. 8(10): 1563-1573.

doi: https://doi.org/10.20546/ijcmas.2019.810.182 